\title{
Experiences with external drainage systems from compact roofs in Norwegian climates
}

\author{
Erlend Andenæs ${ }^{1, *}$, Vegard A. Skagseth ${ }^{1}$, Nora S. Bunkholt ${ }^{2}$, Tore Kvande ${ }^{1}$ and Jardar Lohne ${ }^{1}$ \\ ${ }^{1}$ Norwegian University of Science and Technology (NTNU), Dep. of Civil and Environmental Engineering, 7491 Trondheim, Norway \\ ${ }^{2}$ SINTEF Community, 7465 Trondheim, Norway
}

\begin{abstract}
To reduce loads on urban drainage systems and facilitate local infiltration of stormwater, it is desired to lead runoff water from roofs through external drains and into the local soil. However, in cold climates, situations often arise where water freezes in external drainpipes, damaging the pipes and preventing drainage. This article investigates the perceived feasibility of external drainage when compared against the risk of freezing damage. A literature study investigates mechanics of ice formation in drains and gutters, and under which conditions ice formation poses a risk to the building. Actors in the Norwegian building sector are interviewed about the challenges related to external drainage from compact roofs in several locations in Norway. Findings suggest that external drainage is considered feasible, but many challenges exist. Suggested solutions may conflict with building regulations, either due to risk of damages or through an unreasonably high energy consumption. Passive solutions without heating elements may, however, be feasible in certain climates in Norway. It is suggested that further research follows up the feasibility of using external drainage in relation to local climate and building concepts.
\end{abstract}

\section{Introduction}

Flat, compact roofs in cold climates have traditionally been connected to internal, insulated drainage systems [1]. The main reason for this is frost risk. Heat transfer through the roof may cause snow and ice to melt despite the ambient outside temperature being below freezing. When the melt water runs away from heated surfaces, it may then freeze again and accumulate as ice on cold surfaces. Accumulation of ice on building overhangs can lead to the formation of icicles, which are hazardous to traffic below, and may also damage the building [2, 3]. Ice accumulation must therefore be avoided. This has traditionally been handled by draining melt water into the hot zone of the building and into underground municipal drainage systems buried at frost-free depths.

However, new challenges and requirements of stormwater management might necessitate the decoupling of roof drainage from municipal drainage systems. Great rainfall events may cause surface floods that overwhelm the drainage systems [4], making it vitally important to lead roof runoff elsewhere. New solutions facilitate local infiltration of stormwater by leading roof water into rain beds or onto permeable terrain [5]. However, this solution involves leading water away from the hot zones of the building, and a risk of melt water re-freezing. The compatibility between stormwater management needs and building physics must be investigated.

This paper addresses some of the challenges, benefits, and disadvantages of using exterior drainage from compact roofs. It examines what the construction industry

\footnotetext{
Corresponding author: erlend.andenas@ntnu.no
}

has experienced in the past, both when the solution with external drainage has been successful and when it has not. Data has been collected through 19 interviews with actors in the Norwegian building sector. Interviewees were sought with different roles in the construction sector and operating in different climates. Unfortunately, respondents could not be found from all climate zones of Norway.

The article aims to investigate the following research questions.

1. What is the current practice regarding external drainage from compact roofs in Norway?

2. What are the challenges related to the current practice?

The paper further investigates the use of compact roof with external drainage in three different Norwegian climates, all of which are coastal to some degree. Norway contains other climate zones, including temperate and polar inland climates. Regrettably, no interviewees could be found with experiences with external drainage solutions in inland climates. 


\section{Theory}

\subsection{Stormwater management}

Densification of urban environments and changing weather patterns due to climate change is posing a challenge of stormwater management in many cities worldwide [4-6]. With greater fractions of urban areas being paved with impervious surfaces, local stormwater infiltration is hindered, leading more stormwater to float on the surface where local drainage systems are meant to lead the water safely away. However, with greater rainfall intensity, the capacity of the drainage systems may not be sufficient to drain all the water safely. It is therefore sought to manage stormwater through other means: local infiltration, retention and detention. Runoff water from roofs has traditionally been drained straight to a stormwater drainage system. Research has shown that decoupling roof downpipes from drainage systems can facilitate local infiltration [7]. Several municipalities in Norway are now requiring new buildings to depose of roof runoff locally [8]. In practice, this necessitates that roofs of all types are built with external drainage.

\subsection{Norwegian regulations}

The Norwegian Building Technical Regulations (TEK17) stipulate in §13-12 (2) that: "Roofs shall be designed and executed with sufficient slope and drains to lead rain and snowmelt off the roof. Precipitation, snowmelt and icing should not lead to damages to the building" [9]. Furthermore, the regulation's guidance text states: "On roofs without ventilation (compact roofs), melt water must be led from colder to warmer parts of the roof and drained away frost-free without the use of heating cables" [9].

The regulations are binding, while the guidance text contains recommended solutions that ensure compliance with the regulations [10]. If the guidance text is not followed, and a different solution chosen instead, analyzes must be performed to ascertain whether the requirements of the regulations are met. This can be both resource- and time-consuming, so it is often advantageous to build on pre-accepted solutions if possible.

\subsection{Current practice}

Pre-accepted solutions for drainage from compact, warm roofs are described in the guide to TEK17 §13-12(2) [9] and in the SINTEF Design guides 525.207 Compact roofs [1]. In order to fulfill the requirements for drainage from cold to hot zones in frost-free drains, preferably without the use of heating cables, internal drains are usually used, with the drain placed in a gutter. This means that water can easily drain and that any ice formation around the gutter will melt early. However, depending on the local climate and the design of the roof, it is possible that compact roofs can be built with external drainage. In such cases, the drain is designed as for ventilated roofs. This can be considered, for example, in places with mild climates and little ice and snow.

\subsection{Building physics}

Building elements, including compact roofs, will always have a heat loss from the hot to the cold side. The magnitude of this heat loss depends on the temperature difference across the roof structure, the U-value of the roof and any air leaks through the roof structure [11]. When compact roofs are covered with snow, the snow will act as an extra layer of insulation. As a result, it is possible that the temperature in the lower part of the snow layer will reach its melting point and runoff from the roof will begin [3]. The likelihood of this occurring is increasing with large snow thicknesses, large heat loss through the roof, and outdoor temperatures just below $0{ }^{\circ} \mathrm{C}$. In compact roofs with internal drainage this is not a problem, firstly because the snow melts first around drains due to heat loss through the drains themselves, and secondly because any snowmelt will flow from the cold to the hot side on the roof. With external drainage, snowmelt can, under certain conditions, run from a warmer to a colder zone of the roof, where it will freeze and potentially cause damage to the building, see Fig. 1. An example of roof runoff having re-frozen after exiting a compact roof can be seen in Fig. 2.
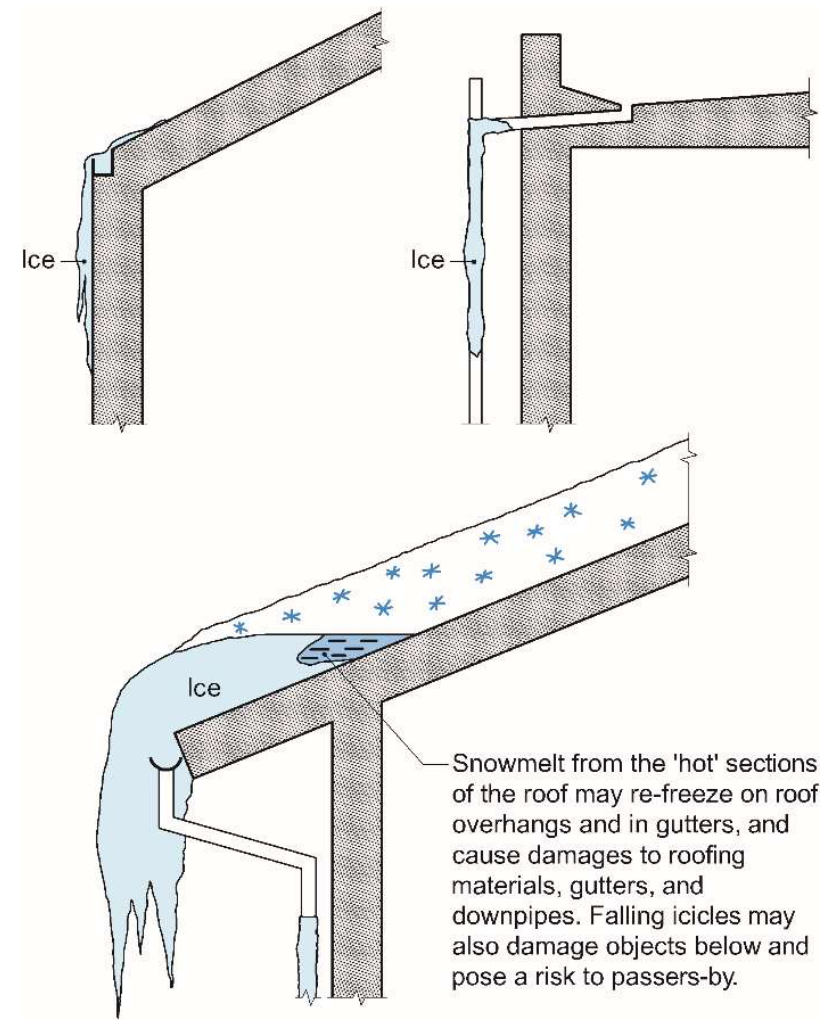

Fig. 1. Ice formation in roof drainage systems. Illustration: SINTEF Community [12] 


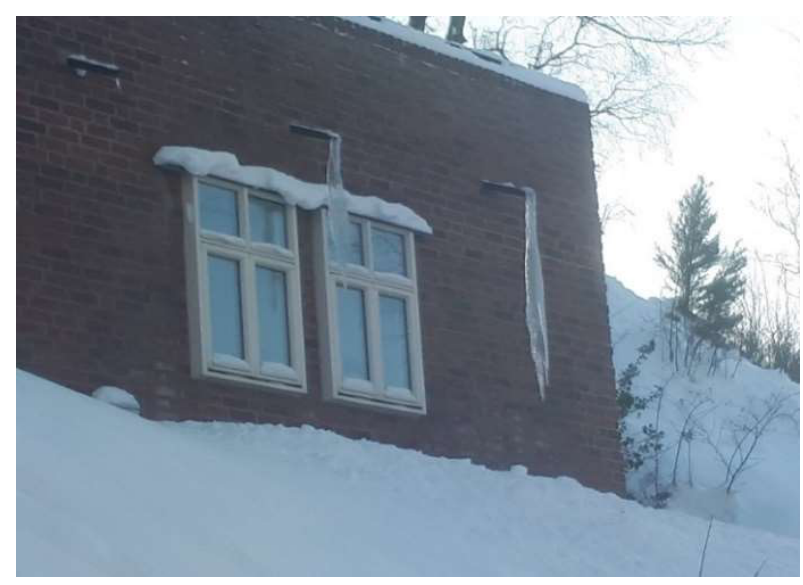

Fig. 2. Snowmelt re-freezing after running off a compact roof through external drainage (photo: Erlend Andenæs).

\section{Method}

A qualitative approach was chosen for the data gathering in this research, with semi-structured interviews as described by Blumberg et al. [13]. 19 persons with relevant expertise in the Norwegian building sector were interviewed about their experiences with external drainage of compact roofs. Below is an overview of the associations of the interview subjects:

- Contractors: 2

- $\quad$ Roofing specialists: 4

- Consulting engineers: 3 (2 building physics, 1 water and wastewater)

- Dwelling contractors: 5

- $\quad$ Product suppliers: 2

- $\quad$ Property developer: 1

- Building sector interest organization: 1

Information gathering was conducted through interviews conducted over the phone and in person throughout the summer of 2019. For the interviews to cover all the important issues, an interview guide was developed. The questions were based on known advantages and disadvantages of external drainage on compact roofs, as well as information from the SINTEF Building Research Design Guides (Byggforskserien) [14]. The questions were made to be open-ended without bias. The various actors interviewed were primarily selected based on the project participants' knowledge of actors who could have experience with the construction solution. In addition, some of the interviewees were contacted after suggestions from other interviewees. Not all questions in the interview guide were asked in all interviews. This depended on who was interviewed and how the actor answered questions. Each interview typically lasted from 15 to 25 minutes.

Before the interviews, an e-mail was sent to each interview subject. This was done for two reasons: to prepare the interviewees and give them some reflection time before conversation, and to give the opportunity to schedule a more suitable time for the interview.

The approach gave time to evaluate the results and write summaries between the conversations. After the interview rounds, summaries were written from the interviews. These summaries are used as a basis for the Results chapter in this paper.

\section{Results}

\subsection{Experiences}

There is considerable variation in the interviewees' experiences with the use of external drainage on compact roofs. Some of the actors have experienced damage to roofs built like this, while others consider the solution preferable to internal drainage. Several parameters that influence the suitability of the solution are mentioned, including geographical location in the country, the actor's role and responsibilities in the project, financial interests, use of the building and architectural conditions. The actors interviewed operate in diverse geographical areas like South-West Norway, the Oslo area and in Nordland near the Arctic circle. Two of the actors only use solutions that are pre-accepted by the SINTEF design guides, while one contractor only uses ventilated sloping roofs, which they regard as a safe solution for handling water. One of the dwelling contractors only recommends internal drainage on compact roofs. They stated they had not been informed about any other solutions used by actors they collaborate with. A few of the actors did not have experience with exterior drains on compact roofs at all but provided information about others who might have. Table 1 gives an overview of some of the actors, their experiences with external drainage from compact roofs, and climate data for their relevant geographical area of operation.

The motivation to choose exterior drainage from compact roofs rather than interior is often that the solution is more cost-effective and provides simpler technical solutions. Many of the actors we interviewed also state that they do not want to use internal drainage due to major consequences if leaks occur in the pipes, and that it is easier to detect a leak outdoors than inside a technical shaft. Based on the survey, this view seems prevalent among actors in coastal regions in South-West Norway. In this area, the climate is usually mild and wet, and if it snows, no snow layer on the roof will last long. None of the interview subjects operating in this area have experienced external drainage pipes blocked by ice. Actors who do not operate in South-West Norway have also mentioned this as a possible location where exterior drains from compact roofs may work well.

Consulting engineers in building physics in the Oslo area do not want to use exterior drains. The climate is unlike in South-West Norway, with colder winters and larger amounts of snow buildup. In cases where external drainage solutions have been used, experience has shown that damage has occurred. One consultant says that whenever he is responsible, and the solution can be avoided, external drainage from compact roofs is never used. Another important point from one of the consultants is that it is often possible to avoid damage through design, but that this often becomes impractical and expensive. 
Table 1. Overview of respondents' experience with external drainage in selected geographical locations.

\begin{tabular}{|c|c|c|c|c|c|c|}
\hline $\begin{array}{l}\text { Actor(s) } \\
\text { interviewed }\end{array}$ & $\begin{array}{l}\text { Geographical } \\
\text { area }\end{array}$ & $\begin{array}{l}\text { Experiences } \\
\text { with external } \\
\text { drainage }\end{array}$ & $\begin{array}{l}\text { Annual } \\
\text { precipitation } \\
{[15]} \\
{[\mathrm{mm} / \text { year }]}\end{array}$ & $\begin{array}{l}\text { Design snow } \\
\text { load }[16] \\
{\left[\mathrm{kN} / \mathbf{m}^{2}\right]}\end{array}$ & $\begin{array}{l}\text { Lowest average } \\
\text { outdoor } \\
\text { temperature, 3d }[17] \\
{\left[{ }^{\circ} \mathbf{C}\right]}\end{array}$ & $\begin{array}{l}\text { Annual } \\
\text { average } \\
\text { temperature, } \\
\mathrm{m}[17]\left[{ }^{\circ} \mathrm{C}\right]\end{array}$ \\
\hline $\begin{array}{l}\text { Contractor, } \\
\text { roofing } \\
\text { specialist }\end{array}$ & $\begin{array}{l}\text { Nordland } \\
\text { (coastal, } \\
\text { north) }\end{array}$ & Good & $\begin{array}{l}\text { Mosjøen: } \\
1680\end{array}$ & $\begin{array}{l}\text { Vefsn: } 5 \\
\text { Mosjøen: } 4 \\
\text { Nesna: } 4\end{array}$ & $\begin{array}{l}\text { Vefsn: }-24.6 \\
\text { Nesna: }-15.6\end{array}$ & $\begin{array}{l}\text { Vefsn: } 4.2 \\
\text { Nesna: } 5.0\end{array}$ \\
\hline $\begin{array}{l}\text { Contractors, } \\
\text { dwelling } \\
\text { contractors }\end{array}$ & $\begin{array}{l}\text { Stavanger/ } \\
\text { Sandnes } \\
\text { (coastal, } \\
\text { south-west) }\end{array}$ & $\begin{array}{l}\text { Preferred } \\
\text { solution }\end{array}$ & $\begin{array}{l}\text { Stavanger: } \\
1250\end{array}$ & $\begin{array}{l}\text { Stavanger/ } \\
\text { Sandnes: } 1.5\end{array}$ & $\begin{array}{l}\text { Stavanger: }-12.8 \\
\text { Sandnes: }-14.9\end{array}$ & $\begin{array}{l}\text { Stavanger: } 7.8 \\
\text { Sandnes: } 7.6\end{array}$ \\
\hline $\begin{array}{l}\text { Consulting } \\
\text { engineers }\end{array}$ & $\begin{array}{l}\text { Oslo area } \\
\text { (inland/ } \\
\text { coastal, east) }\end{array}$ & $\begin{array}{l}\text { Have used, led } \\
\text { to damages }\end{array}$ & $\begin{array}{l}\text { Blindern: } 763 \\
\text { Tryvassh } \varnothing \text { gda: } \\
1200\end{array}$ & $\begin{array}{l}3.5-6.5 \\
\text { (depending } \\
\text { on altitude) }\end{array}$ & Oslo: -19.8 & Oslo: 6.1 \\
\hline
\end{tabular}

The sections below describe solutions for the use of external drainage on compact roofs used in the Norwegian construction sector. Solutions used by industry actors in different geographical areas and general recommended solutions are described.

\subsection{Solutions in different geographical areas}

\subsubsection{South-West Norway}

Actors in coastal areas in South-West Norway have mentioned several different external drainage solutions currently in use. One involves drains recessed in the insulation on the inside of the parapet, with downpipes attached to the outside of the parapet. The roof slopes towards drains with downpipes extending through the parapet. In many situations, a form of funnel or opening has been used in the downpipe so that any ice formation has room to expand.

A solution used on a cabin in a mountain area was also mentioned. This involves gutters protruding from the wall, without the use of downpipes. Rainwater and meltwater will be able to run straight off the roof and into a rock bed. Icicles will also be formed here, but no traffic was planned under the protrusions. The icicles will fall into the rock beds where they do not cause damage. The solution can work well on cabins as they are not always heated and are only used for shorter periods of the year, which will reduce icicle formation.

\subsubsection{Coastal North Norway (Mosjøen)}

Actors operating in the area around Mosjøen describe a solution where the parapet is built on three sides of the roof. The remaining side is built without the parapet, but with a flashing covering the transition from roof to drain. The roofing is fastened to the top of the flashing with the gutter hanging below. The roof is insulated with an average insulation thickness of $250 \mathrm{~mm}$ and a slope towards the chute of 1:40. For larger roofs, the solution can be used with a fall on two sides and / or the use of larger gutters. According to the roofing specialist and the contractor who use the solution, it is not associated with damage. They have not heard of damage due to ice formation on the end of the roof (above the wall) or along the gutter (which will also be colder than the parts of the roof where water will flow from). The solution is pictured in Fig. 3.

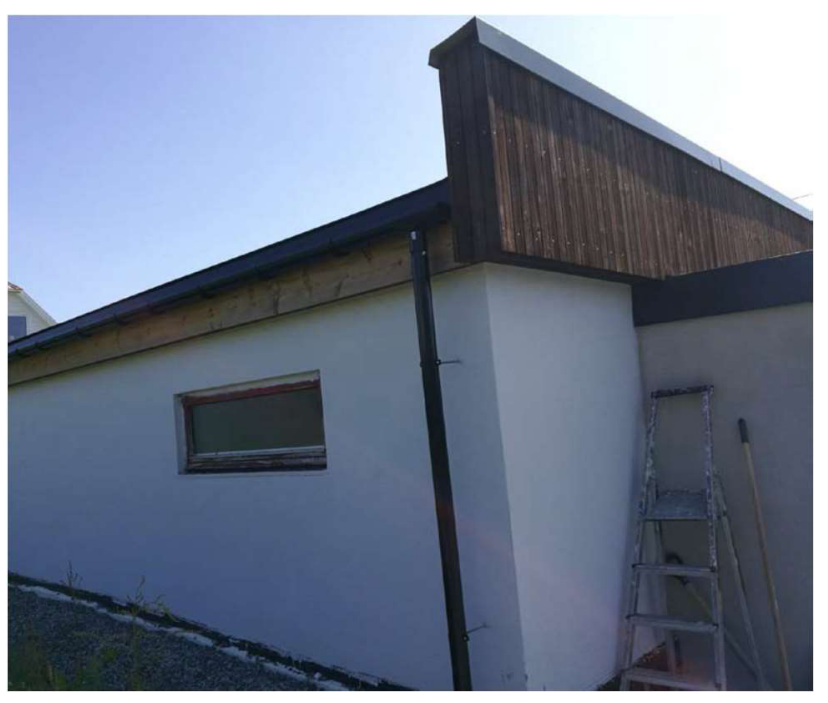

Fig. 3. Solution described by actors in Mosjøen; a compact roof with parapet on three sides and an external gutter on the remaining side. Here pictured at Valderøya outside Ålesund (photo: Vegard Skagseth).

\subsubsection{South-East Norway (Oslo area)}

In the Oslo area, solutions like those in South-West Norway are used, but in this area, there have been problems due to a colder climate, snow that settles on the roof and freezing precipitation. One of the hybrid solutions proposed by Skanska, further discussed in section 4.3.1, is being tested in the Oslo area.

One solution is a roof with a slope towards the parapet and counter wedge at the parapet itself. Water is drained through the parapet into a closed pipe system. However, this solution has been linked to frost and leak damage. A consulting engineer also indicates that the risk of leakage increases with increasing number of penetrations through the parapet.

\footnotetext{
*Corresponding author: erlend.andenas@ntnu.no
} 


\subsection{Other solutions described by industry experts}

\subsubsection{Hybrid internal-external solution}

An interviewee from the construction company Skanska describes a hybrid solution using an internal drain with a reduction valve, draining only a limited amount of water, such as a trickle of snowmelt in sub-zero weather. In conditions where re-freezing of runoff water occurs, the amount of runoff water is very limited. A main external drain will drain large amounts of water from snowmelt in high temperatures, or heavy rain outside the winter season.

\subsubsection{Large-diameter downpipes}

A solution is proposed with a slope towards the center of the roof, where a recessed gutter runs out towards the parapet and into a large-diameter downpipe. A large downpipe takes longer to freeze shut. If the roof is well insulated, the runoff in the cold periods will also be reduced. If the cold periods are short enough, a solution like this may only see a limited amount of ice accumulation before the ice thaws again.

\subsubsection{Active heating}

LORO is a German system combining several solutions, both with reduction valves and heating cables, a recessed gutter in insulation passing through the parapet, and drains mounted directly on the roofing. The system has a high capacity and therefore fewer drains can be used [18]. The Norwegian supplier of the LORO roof dewatering system claims that there has never been any problem with the use of their solution as long as the valves are not mounted against the fall directions and self-regulating heating cable is used and / or the pipes are insulated if there is a risk of frost.

\section{Discussion}

This paper aims to answer the following research questions: the current practice regarding external drainage from compact roofs, eventual challenges arising from the current practice, and whether any improvements could be made.

The guide Byggforskerien 525.207 Compact roofs [1] currently indicates that compact roofs usually must be built with internal drainage, but that external drainage can possibly be used for buildings with special roof shapes (for example arched roofs) and in places with mild climate and little ice and snow [1]. The circumstances are not further specified, and design guides that indicate in which climates and areas compact roofs with external drainage can be built are in demand. Experience gained from this research shows that in the climate of South-West Norway, it is often possible to choose external drainage on compact roofs. In this region the design snow load is comparably low at $1.5 \mathrm{kN} / \mathrm{m}^{2}$, and the design minimum outdoor temperature is in the range -15 to $-12{ }^{\circ} \mathrm{C}[16,17]$. These factors together imply that snow rarely accumulates on roofs in the region, and that the weather is rarely cold enough for the combined temperature gradient through the roof and snowpack to reach zero degrees above the roofing membrane, which is the condition required for snowmelt and re-freezing to occur. Additionally, the winter temperature exceeds $0{ }^{\circ} \mathrm{C}$ often enough that longterm accumulation of ice becomes a very rare phenomenon.

In Oslo, however, the actors who have been interviewed do not have good experiences with the use of compact roofs with external drainage. Several interviewees avoid using this solution, partly because they have experienced damage associated with ice formation around the downpipe. In this area of the country, the design snow load is $3.5-6.5 \mathrm{kN} / \mathrm{m}^{2}$ and design minimum outdoor temperature is $-19.8^{\circ} \mathrm{C}[16,17]$. The combination of snow accumulation and cold leads to great risk of snowmelt and re-freezing. In contrast to coastal climates, the temperature is also more stable, with fewer temperature transitions through the freezing point during winter. This may allow for greater ice accumulation to occur. While the research does not contain any data for inland regions, it can be assumed that external drainage from compact roofs will be even less suitable there, as the design snow load in these regions tends to be higher than in Oslo while the design minimum temperature is even lower. The experience gained from this research shows that the local climate is of great importance for whether external drainage from compact roofs can be used.

Fig. 4 shows a map of the climate zones in the Nordic countries, adapted from [19]. The areas where exterior drainage from compact roofs seem to work well all lie within the Maritime temperate zone, while the solution is shown not to work well in the Continental climate zone. This allows the results obtained in Norway to be extrapolated for the rest of the Nordic countries as well.

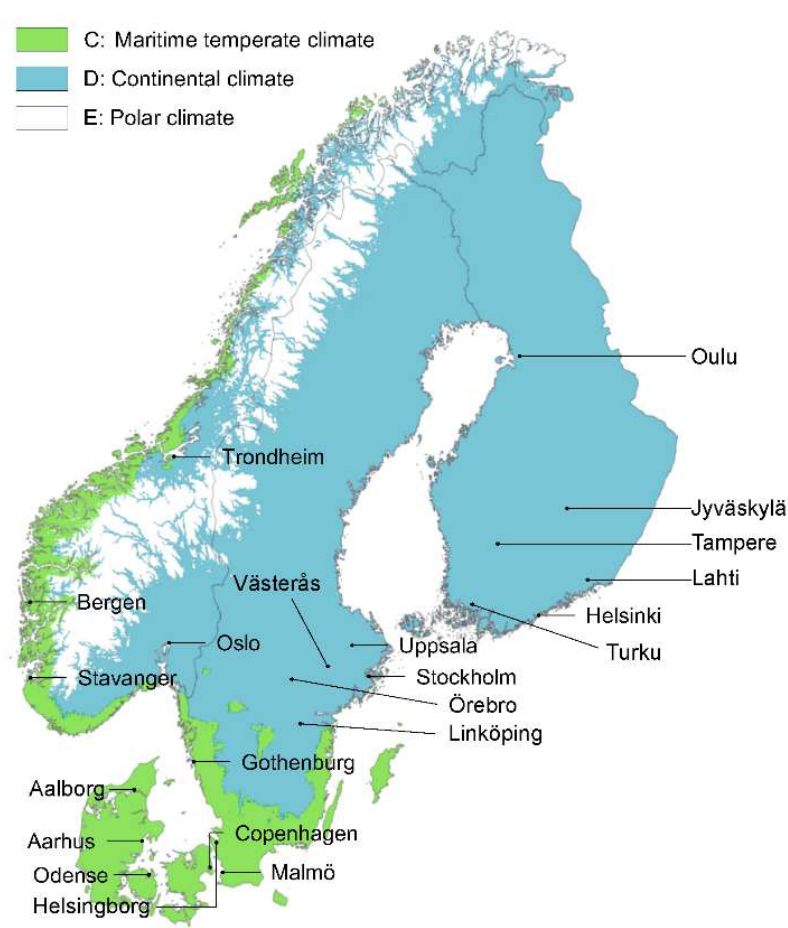

Fig. 4: Climate zone chart for the Nordic countries, from [19]. 
The results suggest that external drainage from compact roofs may be feasible in Denmark and southern Sweden, but not in most of Finland or the Scandinavian peninsula beyond the south and west coasts.

Possible new solutions are being investigated that allow for safe drainage of snowmelt without re-freezing damage, while simultaneously draining water externally when large rain events occur. There appears to be three schools of thought regarding snowmelt: 1) draining it to a hot zone before it can re-freeze, 2) designing drains that aren't easily damaged by re-freezing, and 3) using heating and insulation to prevent re-freezing even in the cold zones. Each solution has its downsides, with the following being main issues respectively: 1) being a relatively expensive solution that requires both internal and external drains, 2) running the risk of accumulating more ice than the drain is designed for, 3) requiring a significant amount of energy for active heating as well as relying on the uninterrupted operation of the system.

\section{Conclusions}

There is an increasing desire to divert roof water to ground level instead of directly into the municipal drainage system. Today, the solutions that can be used for exterior drains on compact roofs are expensive, difficult to implement, not adequately designed, or only possible to use in a limited area of the country due to climatic conditions. Experience gathered shows that solutions with external drainage have worked well in South-West Norway. In the Oslo area, experience suggests that exterior drainage is not suitable for compact roofs, and it can be assumed that this will also be the case in inland climates. Some solutions that have been built or suggested do not comply with the requirements given in TEK17 [9], either by risking damage to the building, or by using heating cables.

For further work, it may be of interest to look more closely at the solutions currently in use, and to investigate the level of risk associated with them. To gain more experience, it is also possible to contact actors in building sectors of other countries where the same challenges arise, and other solutions may be in use. For instance, it was mentioned by one interviewee that external drainage from compact roofs has been used in Sweden to some degree.

Since the risk of icing is climate dependent, it may be of great interest to design a map that gives an overview of areas in Norway that are relevant for the use of compact roofs with external drainage, and areas where this is not recommended. Should any damage occur, the responsibility is usually assigned either to the contractor or the design engineer. Pre-accepted solutions or design guides for compact roofs with external drainage would give the construction industry a better foundation when planning such roofs.

The authors gratefully acknowledge the financial support by the Research Council of Norway and several partners through the SFI Klima 2050 (www.klima2050.no).

\section{References}

1. Byggforskserien 525.207 Kompakte tak. SINTEF Community. (2018)

2. H.L. Grange, L.T. Hendricks. Roof-snow behavior and ice-dam prevention in residential housing. University of Minnesota; (1976).

3. W. Tobiasson, H.R. Trechsel, M.T. Bomberg, Roofs. In: Trechsel HR, Bomberg MT, editors. Moisture Control in Buildings: The Key Factor in Mold Prevention-2nd ed. p. 297-45. (2009)

4. A. Semadeni-Davies, C. Hernebring, G. Svensson, L$\mathrm{G}$. Gustafsson. The impacts of climate change and urbanisation on drainage in Helsingborg, Sweden: Combined sewer system. Journal of Hydrology. 350:100-13. (2008)

5. T.M. Muthanna, E. Sivertsen, D. Kliewer, L. Jotta. Coupling Field Observations and Geographical Information System (GIS)-Based Analysis for Improved Sustainable Urban Drainage Systems (SUDS)

Performance. Sustainability. 10:4683. (2018)

6. Gill SE, Handley JF, Ennos AR, Pauleit S. Adapting Cities for Climate Change: The Role of the Green Infrastructure [Internet]. Available from: https://www.ingentaconnect.com/content/alex/benv/2007 /00000033/00000001/art00008 [cited 2019 Dec 10]. (2007)

7. M.A. Becker, Trinn 1: Reduser overvannet $i$ avløpsnettet ved å frakoble taknedløp. Vann, 04 (2016)

8. O.I. Opheimsbakken, S. Lehn-Hermandsen, T. Helland, E. Borge, H. Colbjørnsen, L. Grimsgaard, et al. Retningslinjer for overvannshåndtering for kommunene Lørenskog, Ralingen og Skedsmo (2017)

9. DiBK. Byggteknisk Forskrift, §13-12 [Internet]. Norwegian Building Authority; Available from: https://dibk.no/byggereglene/byggteknisk-forskrifttek17/13/vi/13-12/ [cited 2019 Dec 10] (2017)

10. DiBK. Veiledning om tekniske krav til byggverk [Internet]. Available from:

https://dibk.no/byggereglene/byggteknisk-forskrifttek17/ [cited 2019 Dec 15] (2017)

11. C-E. Hagentoft, Introduction to Building Physics. 10th ed. Gothenburg, Sweden: Studentlitteratur (2001).

12. Byggforskserien 725.118. Skader i kompakte tak. Arsaker og utbedring. SINTEF Community. (2012)

13. B. Blumberg, D. Cooper, P. Schindler, Business research methods: 2nd European ed. Maidenhead: McGraw-Hill Higher Education. (2008) 
14. SINTEF Community. Byggdetaljer - Byggforskserien [Internet]. Byggforsk.no. Available from: https://www.byggforsk.no/innhold/2/byggdetaljer [cited 2019 Dec 10] (n.d.)

15. Byggforskserien 451.031 Klimadata for dimensjonering mot regnpåkjenning. SINTEF Community. (2013)

16. NS-EN 1991-1-3:2003 + A1:2015 + NA:2018, Eurocode 1: Actions on structures - Part 1-3: General actions - Snow loads. Standard Norge (2003)

17. Byggforskserien 451.021 Klimadata for termisk dimensjonering og frostsikring. SINTEF Community. (2018)

18. Loro. LORO-X takavvanningssystemer [Internet]. Shelby Teknikk AS; Available from: https://static1.squarespace.com/static/51 fa62cfe $4 \mathrm{~b} 01 \mathrm{febf}$ deea593/t/5a21248271c10b5cef0213ea/1512121552818/ Lorotak+2017.pdf (2017)

19. Thodesen B, Kvande T, Tajet HTT, Time B, Lohne J. Adapting green-blue roofs to Nordic climate. Nordic J Arch. 